\title{
Molecular characterization of hemoglobin D Punjab traits and clinical-hematological profile of the patients
}

\author{
Caracterização molecular dos traços de hemoglobina D Punjab e \\ perfil clínico-hematológico dos pacientes
}

\author{
Sanjay Pandey', Rahasya Mani Mishra", Sweta Pandey"', Vineet Shah"v , Renu Saxenav \\ Department of Hematology, All India Institute of Medical Sciences, New Delhi, India
}

\begin{abstract}
'MSc. Senior Research Fellow, Department of Hematology, All India Institute of Medical Sciences, New Delhi, India.

"PhD. Professor, Department of Environmental Biology, Awadhesh Pratap Singh University, Rewa, Madhya Pradesh, India

"'MSc. Student, Department of Hematology, All India Institute of Medical Sciences, New Delhi, India.

"MSc. Senior Research Fellow, Department of Cardiac Biochemistry, All India Institute of Medical Sciences, New Delhi, India.

vMD. Professor, Department of Hematology, All India Institute of Medical Sciences, New Delhi, India.
\end{abstract}

\section{KEY WORDS:}

Hemoglobinopathies.

Hemoglobins.

Chromatography, high pressure liquid.

Thalassemia.

Polymerase chain reaction.

\section{PALAVRAS-CHAVE:}

Hemoglobinopatias.

Hemoglobinas.

Cromatografia líquida de alta pressão.

Talassemia.

Reação em cadeia de polimerase.

\begin{abstract}
CONTEXT AND OBJECTIVE: Hemoglobin ( $\mathrm{Hb}$ ) D hemoglobinopathies are widespread diseases in northwestern India and usually present with mild hemolytic anemia and mild to moderate splenomegaly. The heterozygous form of $\mathrm{Hb} \mathrm{D}$ is clinically silent, but coinheritance of $\mathrm{Hb} \mathrm{D}$ with $\mathrm{Hb} \mathrm{S}$ or beta-thalassemia produces clinically significant conditions like thalassemia intermedia of moderate severity. Under heterozygous conditions with coinheritance of alpha and beta-thalassemia, patients show a degree of clinical variability. Thus, our aim was to molecularly characterize the $\mathrm{Hb} \mathrm{D}$ trait among individuals who were clinically symptomatic because of co-inheritance of alpha deletions or any beta-globin gene mutations.

DESIGN AND SETTING: This was a cross-sectional study conducted in an autonomous tertiary-care hospital. METHODS: Complete blood count and red cell indices were measured using an automated cell analyzer. Quantitative assessment of hemoglobin $\mathrm{Hb}$ F, $\mathrm{Hb}$ A, $\mathrm{Hb}$ A2 and $\mathrm{Hb}$ D was performed by means of high performance liquid chromatography (HPLC). DNA extraction was done using the phenol-chloroform method. Molecular analyses on common alpha deletions and common beta mutations were done using the Gap polymerase chain reaction and Amplification Refractory Mutation System, respectively.

RESULTS: We evaluated 30 patients and found clinical variation in the behavior of $\mathrm{Hb} \mathrm{D}$ traits. In six patients, the $\mathrm{Hb} \mathrm{D}$ traits were clinically symptomatic and behaved like those of thalassemia intermedia. Molecular characterization showed that three out of these six were IVS-1-5 positive.

CONCLUSIONS: HPLC may not be the gold standard for diagnosing symptomatic Hb D Punjab traits. Hence, standard confirmation should include molecular studies.
\end{abstract}

\section{RESUMO}

CONTEXTO E OBJETIVO: Hemoglobinopatias da hemoglobina $(\mathrm{Hb}) \mathrm{D}$ são doenças amplamente disseminadas no noroeste da Índia e geralmente se apresentam com anemia hemolítica leve e esplenomegalia leve a moderada. A forma heterozigótica de Hb D é clinicamente silenciosa, mas co-herança de Hb D com $\mathrm{Hb}$ S ou beta-talassemia produzem condições clinicamente significativas, como talassemia intermediária de gravidade moderada. Em condição heterozigótica com co-herança de alfa e beta-talassemia, pacientes mostram variabilidade clínica. Assim, nosso objetivo foi a caracterização molecular dos traços da Hb D em individuos clinicamente sintomáticos, devido à co-herança de deleções de alfa ou quaisquer mutações gênicas de beta-globina.

TIPO DE ESTUDO E LOCAL: Estudo transversal; realizado em um hospital de cuidado terciário autônomo. MÉTODOS: Hemograma completo e índices de células vermelhas foram medidos pelo analisador automatizado de células. Avaliação quantitativa de hemoglobina Hb F, Hb A, Hb A2 e Hb D foi realizada por cromatografia líquida de alta eficiência. Extração de DNA foi feita pelo método de fenol-clorofórmio. Estudo molecular para deleções comuns de alfa e mutações comuns de beta foi feito por Gap-reação em cadeia da polimerase e amplificação refratária de mutação, respectivamente.

RESULTADOS: Avaliamos 30 pacientes e verificamos variação clínica no comportamento dos traços da Hb D. Em seis pacientes, os traços da Hb D foram clinicamente sintomáticos e se comportavam como os de talassemia intermédia. A caracterização molecular mostrou que três desses seis pacientes eram IVS-1-5 positivos. CONCLUSÕES: HPLC pode não ser o padrão ouro para o diagnóstico de traços de Hb D Punjab sintomáticos. Assim, a confirmação padrão ouro deve incluir estudos moleculares. 


\section{INTRODUCTION}

Hemoglobin ( $\mathrm{Hb})$ D Punjab, also known as Hb D Los Angeles, is an abnormal type of $\mathrm{Hb}$ with an amino acid substitution of glutamine for glutamic acid at codon 121 of the beta-globin gene. $\mathrm{Hb} \mathrm{D}$ occurs in four forms: heterozygous $\mathrm{Hb} \mathrm{D}$ trait, Hb D-thalassemia, Hb SD disease and the rare homozygous $\mathrm{Hb} \mathrm{D}$ disease, which usually presents as mild hemolytic anemia and mild to moderate splenomegaly. ${ }^{1,2}$ $\mathrm{Hb} \mathrm{D}$ Punjab is one of the most commonly observed abnormal hemoglobin variants worldwide, not only in the Punjab region of northwestern India, but also in Italy, Belgium, Austria and Turkey. ${ }^{3-8}$ There are a number of reports of $\mathrm{Hb}$ D Punjab cases from different regions of Turkey, including Denizli province, in the Aegean region..$^{2,79-13}$ Its incidence has been reported by different researchers throughout Turkey with an overall frequency of $0.2 \% .^{13}$ In Denizli province, the most common abnormal variant is $\mathrm{Hb} \mathrm{D}$ Punjab, accounting for $57.8 \%$ of the total abnormal $\mathrm{Hb} \mathrm{S}$ observed in premarital screening. ${ }^{7}$ The Hb D Punjab frequency in Denizli province is similar to the frequency observed in Xinjiang Province, People's Republic of China, where it accounts for $55.6 \%$ of total $\mathrm{Hb}$ variants. ${ }^{14} \mathrm{Hb} \mathrm{D}$ Punjab occurs with greatest prevalence (2\%) among Sikhs in Punjab, India, whereas the reported prevalence rate in Gujarat province, in western India, is $1 \% .^{1}$ Although $\mathrm{Hb} \mathrm{D}$ is not uncommon in India, its homozygous form is very rare..$^{1,2,15}$

\section{OBJECTIVE}

The aims of this study were to molecularly characterize symptomatic Hb D traits and make a comparative analysis on the clinical-hematological data of such patients.

\section{MATERIAL AND METHOD}

This was a cross-sectional study since the data were obtained from patient records rather than prospectively. The subjects recruited for this study presented Hb D Punjab traits. The duration of the sample collection was three years and the study was conducted in the Department of Hematology, All India Institute of Medical Sciences (AIIMS), in New Delhi. Cases of $\mathrm{Hb} \mathrm{D}$ traits that were diagnosed by means of high performance liquid chromatography (HPLC) were included, whereas patients with sickle cell disease, homozygous $\mathrm{Hb} \mathrm{D}$ and $\mathrm{Hb}$ $\mathrm{D}$ with thalassemia, and patients with other hemoglobinopathies were excluded from the study. Blood samples of around $5 \mathrm{ml}$ were collected from the patients after they had signed an informed consent form. Thirty patients, comprising 16 males and 14 females with a median age of 20 years (range 1-43), were included in the study.

Complete blood count and red cell indices were measured by means of an automated cell analyzer (SYSMEX K-4500,
Kobe, Japan). Giemsa-stained peripheral blood smears were examined for red cell morphology. Quantitative assessment of hemoglobin $\mathrm{Hb} \mathrm{F}, \mathrm{Hb} \mathrm{A}, \mathrm{Hb} \mathrm{A} 2$ and $\mathrm{Hb} \mathrm{D}$ was performed using HPLC (Bio-Rad-Variant, Bio Rad, California, United States). DNA extraction was done by means of phenol-chloroform methods, for reasons of cost-effectiveness and availability. Molecular analyses for common alpha deletions and common beta mutations were done in accordance with descriptions in published studies in the literature. ${ }^{16-19}$ Ethidium bromide ( $5 \mu \mathrm{l}$ ) mixed in $2.5 \%$ agarose gel and bromophenol blue loading dye was used to detect the mutation in horizontal gel electrophoresis. Mean values, standard deviation and frequency distribution were used to evaluate the hematological and clinical data.

\section{RESULT}

Six out of the 30 patients were clinically symptomatic and presented anemia, jaundice, pallor and weaknesses. The patients' peripheral smears showed microcytic hypochromic red cells with few target cells. A mild degree of anisopoikilocytosis was noticed. Six $\mathrm{Hb} \mathrm{D}$ patients presented $\mathrm{Hb} \mathrm{A} 2$ ranges of $4 \%$ to $6.5 \%$, with low mean $\mathrm{Hb}(8.3 \pm 3.0 \mathrm{~g} / \mathrm{dl})$, serum iron $(35.2 \pm 3.4 \mu \mathrm{g} / \mathrm{dl})$ and red cell indices. Their hematological features included $\mathrm{Hb} \mathrm{F}$ (normal range $<1.5 \%$ ) and $\mathrm{Hb}$ A2 (normal range $<3.6 \%$ ). The levels were within the normal range in the remaining 24 patients, and all were asymptomatic. None of the patients had alpha deletions. Out of the six symptomatic patients, three patients were IVS1-5 positive (Figure 1). All the 24 asymptomatic Hb D patients were negative for beta thalassemia mutations. Details of the hematological profile are given in Table 1.

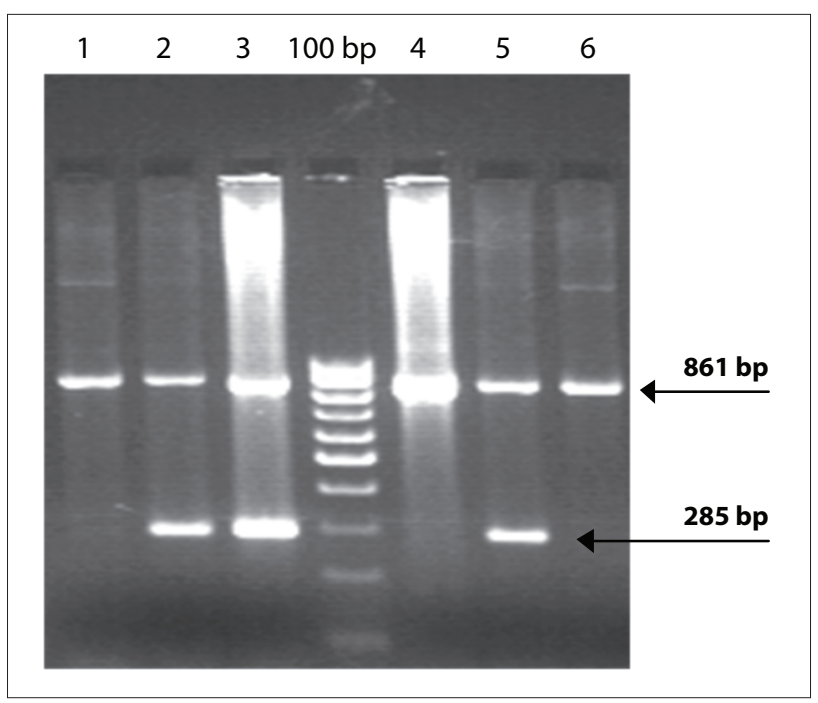

Figure 1. PCR result from six symptomatic patients, in which lanes 2, 3 and 5 are positive for IVS 1-5 mutation ( $b p=$ base pairs). 
Table 1. Comparative hematological profile

\begin{tabular}{lcc}
\multicolumn{3}{c}{ Mean \pm standard deviation } \\
\hline Hematological parameters & $\begin{array}{c}\text { Symptomatic Hb D } \\
\mathbf{n}=\mathbf{6}\end{array}$ & $\begin{array}{c}\text { Asymptomatic Hb D } \\
\mathbf{n}=\mathbf{2 4}\end{array}$ \\
$\mathrm{Hb} \mathrm{A0}$ & $48.6 \pm 3.2$ & $51.2 \pm 8.9$ \\
$\mathrm{Hb} \mathrm{A2}$ & $4.2 \pm 1.8$ & $2.2 \pm 1.7$ \\
$\mathrm{Hb} \mathrm{F}$ & $2.5 \pm 1.3$ & $1.2 \pm 0.4$ \\
$\mathrm{Hb} \mathrm{D}$ & $42.6 \pm 3.5$ & $39.0 \pm 10.8$ \\
Red blood cells $($ millions/ $\mu \mathrm{l})$ & $3.2 \pm 1.7$ & $4.6 \pm 1.0$ \\
Hemoglobin $(\mathrm{g} / \mathrm{dl})$ & $8.3 \pm 3.0$ & $11.4 \pm 3.2$ \\
Hematocrit $(\%)$ & $27.2 \pm 2.6$ & $30.8 \pm 7.9$ \\
Mean corpuscular volume $(\mathrm{fl})$ & $72.3 \pm 5.4$ & $74.5 \pm 11.2$ \\
Mean corpuscular hemoglobin $(\mathrm{pg})$ & $22.7 \pm 2.3$ & $24.9 \pm 4.9$ \\
Mean corpuscular hemoglobin & $25.3 \pm 2.4$ & $28.2 \pm 3.5$ \\
concentration $(\mathrm{g} / \mathrm{dl})$ & & \\
Serum iron $(\mu \mathrm{g} / \mathrm{dl})$ & $35.2 \pm 3.4$ & $75.6 \pm 8.3$
\end{tabular}

$\mathrm{Hb}=$ hemoglobin.

\section{DISCUSSION}

Homozygous $\mathrm{Hb} \mathrm{D}$ disease is rare and usually presents with mild hemolytic anemia and mild to moderate splenomegaly. Heterozygous $\mathrm{Hb} \mathrm{D}$ is a clinically silent condition, but coinheritance of $\mathrm{Hb} \mathrm{D}$ with $\mathrm{Hb} \mathrm{S}$ or beta thalassemia produces clinically significant conditions like sickle cell anemia and chronic hemolytic anemia of moderate severity. Although $\mathrm{Hb} \mathrm{D}$ is not uncommon in India, its homozygous form is very rare ${ }^{1,2,15}$ and very few case reports have been reported. ${ }^{20}$ The major concern in ruling out $\mathrm{Hb} \mathrm{D}$ beta-zero thalassemia is that homozygous $\mathrm{Hb} \mathrm{D}$ disease causes mild hemolytic anemia, but coinheritance of betazero thalassemia seems to produce deleterious effects relating to the presentation of $\mathrm{Hb} \mathrm{D}$ disease, thus leading to chronic hemolytic anemia of moderate severity. ${ }^{21}$ An association between $\mathrm{Hb} \mathrm{D}$ and hematological malignancies has also been reported. ${ }^{22}$ Earlier studies from Pakistan, Iran, United Arab Emirates and Mexico have shown that the clinical presentation of $\mathrm{Hb}$ SD disease cases is similar to that of patients with the severe form of sickle cell anemia. ${ }^{23,24}$ On the other hand, reports from India have shown variable clinical manifestations of Hb SD disease..$^{25,26}$

There are no detailed reports on the clinical and hematological profile of $\mathrm{Hb} \mathrm{D}$ patients, and only a few case reports have been published. ${ }^{20}$ In our sample, six patients with $\mathrm{Hb} \mathrm{D}$ traits were clinically symptomatic and the disease behavior was like cases of thalassemia intermedia. However, the red cell indices were low, which may have been due to coinheritance of either alpha deletion or beta mutation. Therefore, it is necessary to conduct molecular analyses for alpha and beta mutations in these cases, in order to ascertain the factors causing modulation of disease severity. The molecular diagnosis showed that three out of these six cases were IVS1-5 positive. The other three clinically symptomatic cases may have been caused by some other disease that had not been characterized. Factors such as environmental influence, genetic polymorphism in the beta-globin gene clusters, expression of fetal hemoglobin and coinheritance of alpha thalassemia may contribute towards the diversity of disease conditions. A report from Saudi Arabia has also emphasized the importance of careful analysis of the electrophoresis results and the usefulness of molecular studies in premarital screening and other hemoglobinopathy screening programs. ${ }^{27}$ A study in Spain concluded that the hematological picture revealed that $\mathrm{Hb} \mathrm{D}$ Punjab was a mild condition, but that the factor reliably responsible for the phenotype was an imbalance in globin chain synthesis, because of frameshift CD 8/9 (+ G) beta-zero thalassemia mutation..$^{28}$ A hematological and molecular report on $\mathrm{Hb} \mathrm{D}$ Iran associated with betazero thalassemia (619 base-pair deletion) mutations showed a hypochromic, microcytic red cell picture with reduced red cell indices. ${ }^{29}$ Only a few case reports are available in $\mathrm{Hb} \mathrm{D}$ hemoglobinopathies. None of these investigations were on large populations of $\mathrm{Hb} \mathrm{D}$ hemoglobinopathies. Therefore, controversy still exists with regard to the clinical features of $\mathrm{Hb} \mathrm{D}$ coinheritance with either alpha deletions or beta mutations. However, IVS 1-5 $(\mathrm{G} \rightarrow \mathrm{C})$ is the commonest beta globin gene mutation in India ${ }^{30}$ and has a severe effect on the clinical phenotype of thalassemia and sickle beta thalassemia patients.

\section{CONCLUSIONS}

The diversified nature of $\mathrm{Hb} \mathrm{D}$ Punjab traits is due to interaction of other factors that act epistatically on the clinical severity of the disease, given that the HPLC results are contradictory with the clinical findings. Thus, it is strongly recommended that molecular studies should be conducted.

\section{REFERENCES}

1. Lukens JN. The Abnormal Hemoglobins: General Principles. In. Lee GR, Foerster J, Lukens J, Paraskevas F, Greer JP, Rodgers GM, editors. Wintrobe's Clinical Hematology. 10 ${ }^{\text {th }}$ ed. Baltimore: Lippincott Williams \& Wilkins; 1998. p. 1329-45

2. Ozsoylu S. Homozygous hemoglobin D Punjab. Acta Haematol. 1970;43(6):353-9.

3. Li HJ, Zhao XN, Qin F, et al. Abnormal hemoglobins in the Silk Road region of China. Hum Genet. 1990;86(2):231-5.

4. Fioretti G, De Angioletti M, Pagano L, et al. DNA polymorphisms associated with $\mathrm{Hb}$ D-Los Angeles [beta 121(GH4)Glu-->Gln] in southern Italy. Hemoglobin. 1993;17(1):9-17.

5. Husquinet H, Parent MT, Schoos-Barbette S, et al. Hemoglobin D-Los Angeles [beta 121(GH4)Glu----Gln] in the Province of Liège, Belgium. Hemoglobin. 1986;10(6):587-92

6. Lischka A, Pollak A, Bauer K, Aschauer H, Braunitzer G. Hemoglobin D "Los Angeles" in an Austrian family: biochemical identification, clinical aspects, and kindred study. Hemoglobin. 1984;8(4):353-61.

7. Atalay EO, Koyuncu H, Turgut B, et al. High incidence of Hb D-Los Angeles [beta 121(GH4)Glu--> Gln] in Denizli Province, Aegean region of Turkey. Hemoglobin. 2005;29(4):307-10 
8. Fucharoen S, Changtrakun Y, Surapot S, Fucharoen G, Sanchaisuriya K. Molecular characterization of Hb D-Punjab [beta121(GH4)Glu-->GIn] in Thailand. Hemoglobin. 2002;26(3):261-9.

9. Yildiz S, Atalay A, Bagci H, Atalay EO. Beta-Thalassemia mutations in Denizli province of Turkey. Turk J Haematol. 2005;22(1):19-23.

10. Canatan D, Akar N, Arcasoy A. Hb D-Los Angeles/ßIVS-I-110 (G $\rightarrow$ A) combination in a Turkish woman. Turk J Med Sci. 1992;16(8):585-6.

11. Bircan I, Sisli S, Güven A, et al. Hemoglobinopathies in the district of Antalya, Turkey. Pediatr Hematol Oncol. 1993;10(3):289-91.

12. Irken $G$, Oren $H$, Undar B, et al. Analysis of thalassemia syndromes and abnormal hemoglobins in patients from the Aegean region of Turkey. Turk J Pediatr. 2002;44(1):21-4.

13. Altay C. Abnormal hemoglobins in Turkey. Turk J Haematol. 2002;19(1):63-74.

14. Zeng YT, Huang SZ, Ren ZR, Li HJ. Identification of Hb D-Punjab gene: application of DNA amplification in the study of abnormal hemoglobins. Am J Hum Genet. 1989;44(6):886-9.

15. Firkin F, Chesterman C, Penington D, Rush B. Disorders of Hemoglobin Structure and Synthesis. de Gruchi's Clinical Haematology in Medical Practice. 5th ed. Oxford: Blackwell Science; 1996. p. 137-71.

16. Baysal E, Huisman TH. Detection of common deletional alpha-thalassemia-2 determinants by PCR. Am J Hematol. 1994;46(3):208-13.

17. Shaji RV, Eunice SE, Baidya S, Srivastava A, Chandy M. Determination of the breakpoint and molecular diagnosis of a common alphathalassemia-1 deletion in the Indian population. Br J Haematol. 2003;123(5):942-7.

18. Chang JG, Lee LS, Lin CP, Chen PH, Chen CP. Rapid diagnosis of alpha-thalassemia-1 of southeast Asia type and hydrops fetalis by polymerase chain reaction. Blood. 1991;78(3):853-4.

19. Varawalla NY, Old JM, Sarkar R, Venkatesan R, Weatherall DJ. The spectrum of beta-thalassemia mutations on the Indian subcontinent: the basis for prenatal diagnosis. $\mathrm{Br} J$ Haematol. 1991;78(2):242-7.

20. Jain RC. Hemoglobin D disease: report of a case. Am J Clin Pathol. 1971;56(1):40-2.

21. Ahmed M, Stuhrmann M, Bashawri L, Kühnau W, El-Harith EH. The beta-globin genotype E121Q/W15X (cd121GAA-->CAA/cd15TGG-$>$ TGA) underlines $\mathrm{Hb}$ d/beta-(0) thalassaemia marked by domination of haemoglobin D. Ann Hematol. 2001; 80(11):629-33.

22. Dash S, Kumar S, Dash RJ. Hematological malignancy in hemoglobin D disease. Am J Hematol. 1988;27(4):305.

23. Perea FJ, Casas-Castañeda M, Villalobos-Arámbula AR, et al. Hb D-Los Angeles associated with $\mathrm{Hb} \mathrm{S}$ or beta-thalassemia in four Mexican Mestizo families. Hemoglobin. 1999;23(3):231-7.

24. el-Kalla S, Mathews AR. Hb D-Punjab in the United Arab Emirates. Hemoglobin. 1997;21(4):369-75.

25. Tyagi S, Marwaha N, ParmarV, Basu S. Sickle cell hemoglobin-D Punjab disease (Compound Heterozygous state). Ind J Hematol Blood Transf. 2000;18:31-2.
26. Panigrahi I, Agarwal S, Signhal P. HbD-Punjab associated with HbS:A report of two cases from India. Ind J Hematol Blood Transf. 2000;18:86-7.

27. Owaidah TM, Al-Saleh MM, Al-Hellani AM. Hemoglobin D/betathalassemia and beta-thalassemia major in a Saudi family. Saudi Med J. 2005;26(4):674-7.

28. Ropero P, González FA, Sánchez J, et al. [The association of beta zerothalassemia and Hb D Punjab in a family of Indian origin. The second case reported in Spain]. Med Clin (Barc). 1997;108(10):385-8.

29. Agrawal MG,Bhanushali AA, Dedhia P, et al. Compound heterozygosity of Hb D(Iran) (beta(22) Glu--> Gln) and beta(0)-thalassemia (619 bpdeletion) in India. Eur J Haematol. 2007;79(3):248-50.

30. Mukherjee MB, Nadkarni AH, Gorakshakar AC, et al. Clinical, hematologic and molecular variability of sickle cell- $\beta$ thalassemia in western India. Indian J Hum Genet. 2010;16(3):154-8

Sources of funding: Indian Medical Research Council, New Delhi, India

Conflict of interest: None

Date of first submission: July 11, 2011

Last received: January 16, 2012

Accepted: January 18, 2012

\section{Address for correspondence:}

Renu Saxena

Department of Haematology

I. R. C. H. Building (1 ${ }^{\text {st }}$ floor)

All India Institute of Medical Sciences

Ansari Nagar

New Delhi - 110 029, India.

Phone: 91-011-26594670

Phone/Fax: 91-011-26588663

E-mail: renusax@hotmail.com

E-mail: pandeysanjaybt@rediffmail.com 